\title{
PENERAPAN PENCERITAAN TERBATAS PADA PENYUTRADARAAN FILM FIKSI "SASANALAYA"
}

\author{
Arbani Abdurohman Annas \\ Arif Eko Suprihono \\ Gregorius Arya Dhipayana \\ Jurusan Film \& Televisi, Fakultas Seni Media Rekam, Institut Seni Indonesia Yogyakarta \\ Jl. Parangtritis km. 6.5 Yogyakarta Telp. (0274) 381047
}

\begin{abstract}
ABSTRAK
Skripsi karya seni berjudul Penerapan Penceritaan Terbatas pada Penyutradaraan Film Fiksi "Sasanalaya" menggunakan teknik tersebut untuk menciptakan efek kejutan dan membuat penonton menduga-duga adegan dalam film. Objek penciptaan karya seni ini adalah film fiksi berjudul "Sasanalaya" yang menceritakan tentang Giman dan Ummi yang sedang mencoba meyakinkan Ririn untuk membicarakan tentang wasiat Bapak yang ingin mewakafkan tanahnya.

Penerapan penceritaan terbatas dilakukan dengan menyembunyikan informasi bahwa tanah yang sedang diurus akan diwakafkan. Informasi yang diberikan kepada penonton akan disembunyikan dan dipaparkan sedikit demi sedikit. Sehingga penonton akan mendugaduga adegan setelahnya. Konsep penciptaan karya ini ditekankan pada penerapan penceritaan terbatas di mana kamera tidak pernah lepas dari tokoh utama. Penonton akan mengikuti alur cerita melalui tokoh bernama Giman. Dengan begitu informasi yang didapatkan oleh penonton akan terbatas pada informasi yang juga diketahui oleh Giman. Dengan menyembunyikan informasi tersebut penonton akan dibuat penasaran dan memberikan efek kejutan ketika informasi tersebut diberikan.
\end{abstract}

kata kunci : penceritaan terbatas, film fiksi, penyutradaraan

\section{PENDAHULUAN}

Permasalahan ekonomi sudah menjadi hal klasik. Mulai dari kalangan grassroot sampai urusan negara sudah pasti memiliki permasalahannya sendiri. Permasalahan itu terkadang bisa dikesampingkan. Dalam kehidupan sosial, manusia dapat saling bantu satu sama lain. Setiap orang akan mati dan harta kekayaannya tidak akan dibawanya, namun akan ditinggalkan kepada ahli warisnya. Hal itu menjadi ide cerita dalam sebuah film fiksi dengan judul "Sasanalaya".
Film "Sasanalaya" menceritakan tentang Giman dan keluarganya memiliki masalah ekonomi di sisi lain memiliki keinginan untuk melaksanakan wasiat bapak. Naskah yang digunakan merupakan character driven story, sehingga konflik dan alur cerita akan dibawakan oleh seorang tokoh. Penonton akan mengikuti alur cerita melalui sudut pandang tokoh utama bernama Giman. Untuk itu akan diterapkan penceritaan terbatas di mana cerita hanya mengikuti satu tokoh cerita. Informasi kepada penonton akan disembunyikan untuk 
memberi efek penasaran. Meskipun pada akhir cerita informasinya akan dimunculkan. Film "Sasanalaya" merupakan film dengan genre drama yang dikemas secara natural melalui kehidupan sehari- hari. Sehingga meskipun isu cerita yang diambil cukup berat tapi pembawaan cerita dibuat dengan sederhana melalui kehidupan sehari-hari tokoh Giman.

Film ini mengangkat permasalahan tentang semakin meningkatnya populasi dunia maka kedepannya orang mati juga akan semakin banyak. Semakin penuhnya kuburan bisa jadi tidak ada ruang lagi untuk generasi berikutnya. Kecuali diadakan pembebasan lahan untuk membuat kuburan baru. Kembali kepada permasalahan awal, faktor ekonomi membuat pemilik tanah enggan melepas tanahnya untuk dijadikan kuburan.

Rencana pengadaan lahan pemakaman yang sudah sejak tahun 2015, hingga tahun ini ternyata belum menjadi prioritas. Dalam APBD 2017, alokasi anggaran tersebut sama sekali belum muncul. Padahal kebutuhan lahan pemakaman baru sudah cukup mendesak. (Kedaulatan Rakyat, 26 Januari 2017)

Bahkan di kalangan pemerintah wacana untuk membuat makam baru belum menjadi prioritas, sehingga warga miskin kesusahan untuk mendapat makam karena setiap tahun harga bedah bumi semakin meningkat. Warga kota selama ini beralih ke pemakaman umum atau pemakaman keluarga di pedesaan. Hal di atas menjadi dasar ide cerita pada film "Sasanalaya".

Berawal dari isu yang sering terjadi pada kehidupan sehari-hari masyarakat umum muncul ide tentang film berjudul "Sasanalaya". Film "Sasanalaya" menunjukkan persoalan tentang keluarga yang hendak membicarakan tanah peninggalan Bapak. Selain itu film ini akan mengikuti alur tokoh Giman, sehingga penonton diajak untuk melihat dari sudut pandang Giman. Diterapkan teknik narasi terbatas agar memberi efek penasaran dan membuat penonton ingin melihat film sampai akhir. Karena penonton hanya mengetahui informasi sama seperti Giman atau lebih sedikit.

Penceritaan terbatas adalah informasi cerita yang dibatasi dan terikat hanya pada satu karakter saja. Penonton hanya mengetahui serta mengalami peristiwa seperti apa yang diketahui dan dialami oleh karakter yang bersangkutan. (Pratista, 2008:39-40) Mata kamera tidak pernah lepas dari tokoh utama. Informasi yang diberikan kepada penonton akan diberikan sedikit demi sedikit dan disembunyikan. Penonton akan dibuat penasaran karena ada informasi yang tidak diketahui penonton. 
Konsep utama pada film "Sasanalaya" adalah memberi pengalaman pada penonton seperti apa yang dirasakan tokoh utama. Sudut pandang cerita yang digunakan akan mengikuti alur Giman. Untuk mendapatkan hal itu penuturan cerita yang dilakukan akan melalui penceritaan terbatas. Penonton akan terus bersama tokoh utama bernama Giman dalam film itu. Penonton akan dibuat penasaran dengan apa yang sedang dilakukan atau akan dilakukan Giman berikutnya. Selain itu pengadeganan pada film ini dibuat secara natural, di mana adegan yang dilakukan dibuat seperti apa yang biasa terjadi di dunia nyata. Melalui tokoh Giman penonton akan diajak untuk bersimpati pada tokoh pada film "Sasanalaya".

Penyutradaraan pada film "Sasanalaya" menggunakan tipe penyutradaraan sebagai koordinator. Sutradara bertugas untuk menjaga semua aspek tetap sesuai dengan konsep utama di mana eksekusi dikembalikan kepada persepsi setiap bagian dan pemain pada film. Hal itu digunakan agar hasil karya dapat lebih berwarna karena setiap pemain akan mengimplementasikan karakter sesuai dengan kemampuan yang dimilikinya, selain untuk menghemat waktu latihan pemain. Hal yang harus diperhatikan dalam penyutradaraan ini ialah pemain harus memiliki kemampuan berakting dan mengimplementasi naskah secara mandiri. Sutradara akan terus mengarahkan pemain, hingga pemain menemukan karakter yang diharapkan, sehingga pengadeganan yang dilakukan pada film ini terjadi secara natural.

Film "Sasanalaya" merupakan film drama fiksi di mana alur cerita mengikuti tokoh Giman, sehingga penonton mengetahui peristiwa yang terjadi melalui tokoh Giman. Konflik yang dimunculkan melalui kegiatan seharihari tokoh pada cerita. Genre pada film "Sasanalaya" lebih mengarah pada genre melodrama namun dikemas melalui kegiatan sehari-hari. Konflik yang dimunculkan pada film ini merupakan perdebatan di ruang keluarga, meskipun isu yang mereka bicarakan merupakan sebuah tanah peninggalan bapak yang akan diwakafkan. Pengadeganan pada film "Sasanalaya" di buat secara natural atau seperti apa yang biasa terjadi di dunia nyata, sehingga meskipun dengan genre film "Sasanalaya" termasuk dalam genre melodrama namun penataan adegan pada film "Sasanalaya" tidak terlalu melankolis, emosional, maupun sentimental namun dapat menarik simpati penonton dengan memperlihatkan sesuatu atau konflik yang biasa dilihat oleh penonton.

Film ini akan dibagi menjadi beberapa bagian utama di mana setiap bagian memiliki turning point atau 
peralihan-peralihan sebagai penghubung antar satu permasalahan dengan permasalahan lainnya. Informasi yang diberikan tiap scene akan dibatasi untuk dimunculkan di scene lainnya. Peralihan juga digunakan sebagai pengalihan perhatian untuk penonton terhadap permasalahan utama pada film ini. Penonton selalu dibawa dengan permasalahan baru dan dibuat penasaran dengan informasi yang masih disembunyikan.

Penerapan penceritaan terbatas pada film ini juga berupa pemecahan informasi ke dalam beberapa scene yang terpisah. Contohnya pada adegan makam (scene 8), Giman melihat sekitar makam sudah sangat penuh. Ia bahkan kesulitan untuk berjalan. Implikasi pada adegan itu adalah pada adegan di Rumah Duka. Informasi pada kedua adegan itu saling berkaitan. Pada adegan itu isu yang dibicarakan warga merupakan penuhnya lahan makam, di mana jika ada yang meninggal harus membedah kuburan dan menumpukkannya. Meskipun dua adegan di atas terpisah namun informasi dari kedua scene itu saling berkaitan satu sama lain.

Sudut kamera subyektif digunakan untuk mendukung penerapan penceritaan terbatas pada film "Sasanalaya". Penceritaan terbatas dapat memiliki derajat tertinggi melalui teknik subyektif kamera (Pratista, 2008:40) Melalui angle 190 kamera subjektif penonton diajak terlibat dalam film melalui kontak mata dengan pemeran dalam film sekaligus terlibat secara emosional terhadap pemeran.

Seperti gambar di atas tokoh itu seolah menawarkan minuman kepada penonton. Penggunaan angle kamera subjektif pada film "Sasanalaya" akan diterapkan pada scene yang terjadi sebuah percakapan atau peristiwa yang bersangkutan langsung dengan Giman.

Penataan artistik pada film ini diatur agar mendukung naratif dari film "Sasanalaya". Misalnya untuk menunjukkan penuhnya makan maka pada adegan Giman berada di makam dan melihat sekitar. Lokasi makam harus diatur agar benar-benar terlihat penuh. Begitu pula dengan adegan di Rumah Duka, properti- properti pendukung yang dapat memperlihatkan kegiatan prosesi pemberangkatan jenazah harus diperlihatkan, sehingga penonton dapat langsung mengidentifikasi sebuah adegan.

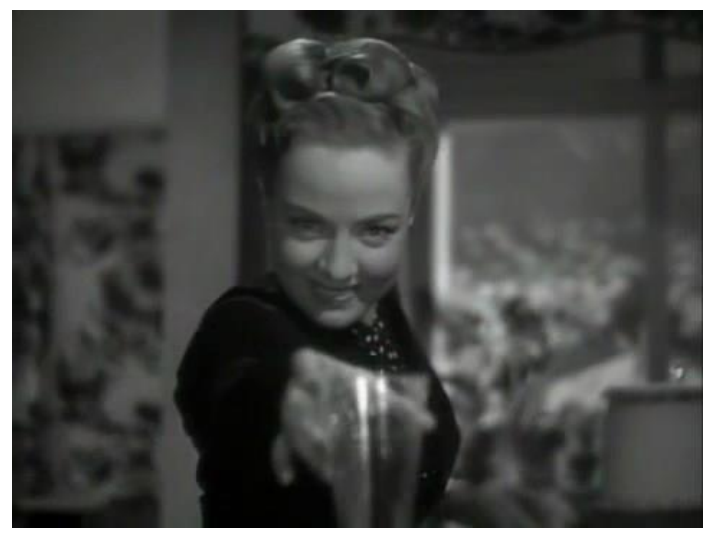

Gambar 1 Referensi penggunaan subyektif shot 
Latar yang digunakan merupakan pedesaan di pinggiran Yogyakarta. Hal ini juga akan mempengaruhi keseluruhan konsep teknis pada film ini. Penataan artistik dari seluruh aspek teknis pada film ini dapat dengan mudah menunjukkan setting film. Terutama menunjukkan kearifan lokal yang hendak diangkat dalam film ini, sehingga latar Yogyakarta tidak hanya sekedar latar tempat saja namun juga menjadi latar kebudayaan pada film ini. Penataan artistik juga mengacu pada kondisi masyarakat pada saat ini. Meskipun setting yang digunakan merupakan pedesaan dengan menunjukkan pemandangan desa yang masih asri. Latar waktu yang digunakan adalah waktu masa ini. Sehingga konflik-konflik yang muncul cenderung mengacu pada permasalahan modern. Salah satunya dengan menunjukkan smartphone sebagai alat komunikasi jarak jauh. Sehingga terdapat properti dengan teknologi terkini seperti TV LCD, smartphone, dan sebagainya. Hal di atas mengacu pada fenomena yang terjadi pada masa sekarang.

Penataan suara pada film "Sasanalaya" akan dibuat secara natural. di mana pada sebuah adegan akan dibuat seperti kondisi di dunia nyata. Penggunaan musik scoring pada film ini juga akan diminimalisir agar tidak terlalu mengganggu penonton dalam menikmati adegan yang disajikan. Selain itu penggunaan diegetic dan non-diegetic sound juga diterapkan pada film ini. Misalnya terdapat suara dari adegan lain yang dicampurkan pada adegan satunya. Misalnya suara pengumuman masjid yang sedang mengumumkan lelayu. Karena film ini berfokus pada sudut pandang tokoh utama sehingga suara diatur agar mengesankan sudut pandang tokoh utama. Beberapa adegan akan terdapat suara dan dialog latar (dialog off-screen) ketika Giman melakukan aktivitas.

Editing yang dilakukan dalam film ini menggunakan teknik non-linear editing. Karena hasil perekaman gambar berupa file video. Teknik ini akan memudahkan dalam proses editing film "Sasanalaya". Untuk memperkuat kesan naratif terbatas maka akan digunakan teknik cut do cut. Sehingga dapat memberi kejutan-kejutan bagi penontonnya. Teknik itu juga akan mendukung implementasi naskah dari film ini karena alur yang digunakan merupakan alur maju mundur melalui kilas balik. Time compression akan digunakan dengan menggunakan cara suara masuk terlebih dahulu dari gambarnya.

Teknis pengambilan gambar sendiri menggunakan kamera digital dengan resolusi HD hingga 4K, sehingga dapat menghasilkan gambar yang cukup 
jelas dan memudahkan proses pasca produksi. Karena hasil gambar yang dihasilkan berupa file digital. Penataan cahaya juga akan diatur sedemikian rupa agar dapat mendukung mood pada setiap adegan. Menggunakan editing nonlinear, sehingga akan memudahkan proses pasca produksi dari film ini.

\section{Pembahasan}

Penerapan penceritaan terbatas pada film "Sasanalaya" dilakukan dengan mengikuti alur Giman. Kamera tidak pernah lepas dari tokoh Giman, sehingga penonton hanya mengetahui informasi yang didapat dari interaksi Giman. Selain itu penerapan subyektif shot juga dilakukan untuk mendukung penceritaan terbatas untuk membatasi informasi yang diberikan kepada penonton. Informasi yang dibatasi akan memberikan efek penasaran dan penonton akan mendugaduga adegan berikutnya. Selain itu penceritaan terbatas juga dapat memberikan efek penasaran bagi penonton. Pada film "Sasanalaya" informasi tentang tanah yang akan diwakafkan akan disembunyikan seolah tanah itu akan dijual. Informasi diberikan kepada penonton juga sepotong-sepotong, sehingga penonton akan penasaran. Pada akhir film semua akan terungkap dan potongan informasi di awal akan saling berkaitan. Penggunaan character driven story membuat alur sepenuhnya dibawa oleh 192 tokoh Giman. Permasalahan dimunculkan melalui tokoh Giman, penonton selalu mendapatkan informasi melalui tokoh Giman, sehingga penonton mengetahui informasi sama atau kurang dari tokoh Giman.

\section{Alur Cerita}

Alur film "Sasanalaya" menggunakan turning point atau peralihan- peralihan untuk mengalihkan atau memunculkan isu dan konflik dalam film. Hasil akhir dari film "Sasanalaya" dibuat sesuai dengan naskah yang sudah ada. Tidak terdapat perubahan yang signifikan dari naskah film "Sasanalaya". Beberapa adegan diubah karena terjadi perubahan secara visual.

\section{a. Eksposisi}

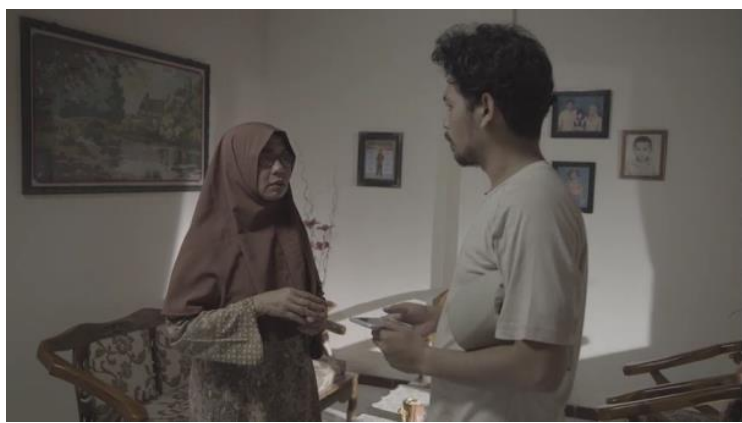

Gambar 2 Screenshot Ummi meminta Giman menelepon Ririn

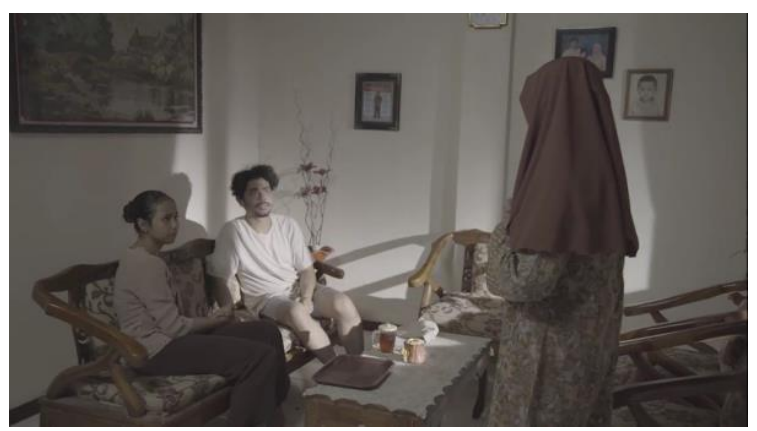

Gambar 3 Screenshot Giman menggeleng 
Giman memasuki rumah kemudian diminta Ummi untuk memanggil anaknya. Giman memandangi Ummi hingga Ummi memintanya untuk cepat. Pada adegan ini penonton akan diberikan informasi tentang keluarga Giman, Ummi yang meminta anaknya pulang untuk berziarah. Istri Giman yang menyiapkan minuman untuknya. Selain itu akan dimunculkan konflik baru berupa sertifikat tanah. Pada akhir adegan Ummi menanyakan kepada Giman soal sertifikat tanah, kemudian Giman hanya menggeleng. Permasalahan tentang sertifikat itu menjadi sebuah peralihan pada alur cerita. Pada bagian ini penonton akan diajak untuk mulai membicarakan tentang permasalahan sertifikat dan melupakan sejenak tentang kertas yang ditemukan pada adegan sebelumnya.

\section{b. Rising Action (Key Turning}

\section{Point 2)}

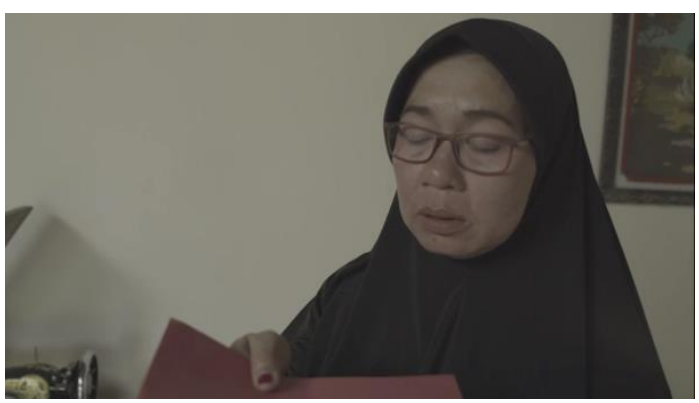

Gambar 4 Screenshot Ummi melihat sertifikat yang dibawa Giman
Informasi yang sudah

diberikan kepada penonton ketika scene 3 yaitu tentang sertifikat akan terjawab di sini. Pada adegan ini penonton akan diberi tahu bahwa Giman melakukan pemutihan sertifikat tanah.

Ummi menanyakan hal itu kemudian meminta Giman untuk membawanya terlebih dahulu kemudian menyuruh untuk berbicara dengan Ririn. Ketika Ririn tiba-tiba muncul Ummi terlihat menyembunyikan sesuatu. Adegan ini juga digunakan untuk membuat penonton menduga-duga. Adanya kemungkinan Ummi akan melakukan sesuatu dengan sertifikatnya. Ummi meminta Ririn dan lainnya untuk segera berangkat sedangkan Giman masuk ke dalam rumah. Permasalahan tentang sertifikat sudah terselesaikan, penonton akan mengetahui permasalahan utama pada film ini bukan tentang sertifikat namun tentang apa yang hendak dilakukan dengan sertifikat itu. Penonton tidak mengetahui bahwa sertifikat itu hendak diwakafkan, penonton hanya mengetahui bahwa Ririn akan tidak menyetujui jika mereka melakukan sesuatu dengan itu. Penonton akan dibuat menduga- 
duga apa yang hendak mereka lakukan.

\section{c. Key Turning Point 2}

Pada adegan ini ditunjukkan betapa penuhnya makam di tempat Giman berada. Implikasi adegan ini adalah di rumah duka ketika isu penuhnya makam sudah menjadi perbincangan warga, bahkan jenazah kesulitan untuk mendapatkan lahan.

Adegan di atas adalah ketika Ummi dan Giman hendak membicarakan soal sertifikat tanah, tetapi Ummi malah membicarakan soal hutangnya. Ririn mulai marah karena Ummi yang suka hutang. Hingga ia menanyakan bahwa sertifikat yang dibawa Ummi apakah mau dijual. Ketika Ummi hendak menjelaskannya tiba- tiba terdengar berita lelayu.

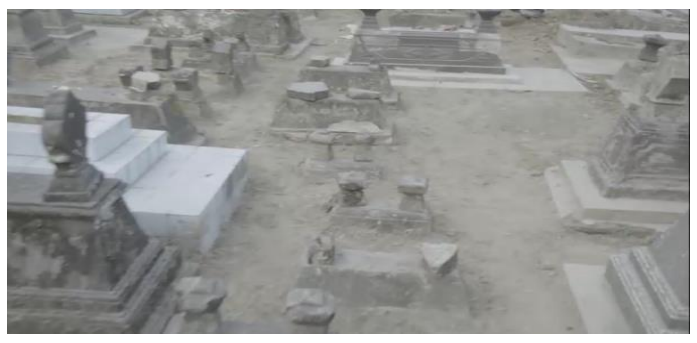

Gambar 5 Screenshot Berjalan di kuburan yang penuh

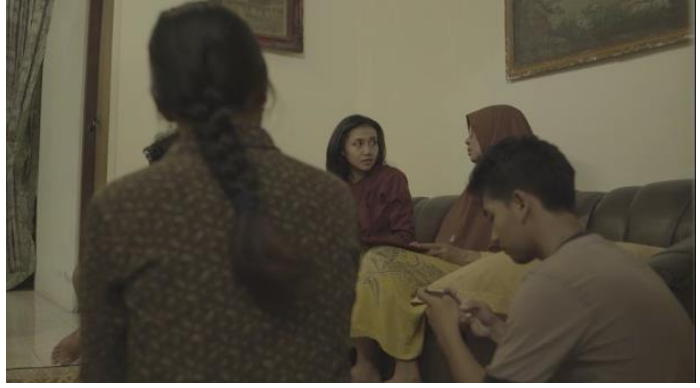

Gambar 6 Screenshot Ririn mengira sertifikat itu hendak digadaikan

Penonton diarahkan untuk menduga bahwa tanah itu akan dijual. Informasi tentang tanah itu akan diwakafkan masih disembunyikan. Isi surat yang ditemukan di awal juga belum dimunculkan. Penonton dibuat menduga-duga dan menelaah kembali informasi yang tersembunyi, sehingga semakin membuat penonton penasaran. Kemudian terdapat peralihan pada titik ini, tiba-tiba terdengar berita lelalyu. Perhatian penonton akan dialihkan lagi dengan munculnya permasalahan baru.

\section{d. Klimaks}

Adegan di rumah duka ditunjukkan dengan shot subyektif sehingga penonton hanya akan mendapat informasi dari mata kamera. 


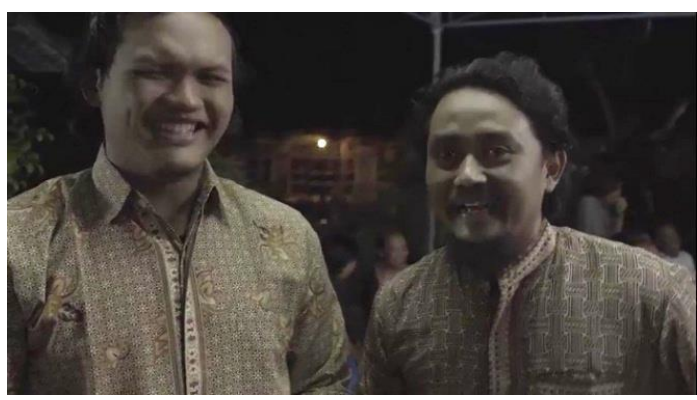

Gambar 7 Screenshot kamera melihat Sarno dan Karto mengobrol

Ketika mendekati dua orang warga yaitu Karno dan Sarno mereka sedang mengobrolkan tentang penuhnya makam. Adegan ini merupakan implikasi dari adegan makam yang sebelumnya. Penonton mulai diberikan informasi bahwa penuhnya makam berhubungan dengan permasalahan Giman. Terlihat dari jauh Pak Dukuh berbincang dengan keluarga Jenazah. Kamera kemudian berjalan ke arah Pak Dukuh. Pak Dukuh mengungkapkan bahwa sedang berusaha mencarikan lahan. Tibatiba ia menoleh ke arah kamera dan terlihat memperhatikan sesuatu kemudian berterima kasih.

Penonton akan mendapatkan informasi bahwa sesuatu dilakukan oleh mata kamera yang kemungkinan adalah Giman atau keluarganya. Penonton akan menduga bahwa keluarga Giman akan membantu proses pemakaman keluarga jenazah dari respons Pak Dukuh. Namun informasi bahwa tanah akan diwakafkan masih belum diperlihatkan. Penonton bisa saja menduga bahwa kemungkinan keluarga Giman mau menumpukkan jenazah di makam bapak.

Giman terlihat mengambil sepucuk surat di lemari kemudian menuju ruang tengah. Terdengar Ririn yang berteriak tidak setuju kepada Ummi. Ummi mencoba menenangkan Ririn Giman menghampirinya kemudian mereka duduk sambil mengobrol. Ririn terlihat menenangkan dirinya kemudian mulai berbicara lagi. Giman menasihati Ummi dan Giman untuk menyimpan tanah mereka terlebih dahulu.

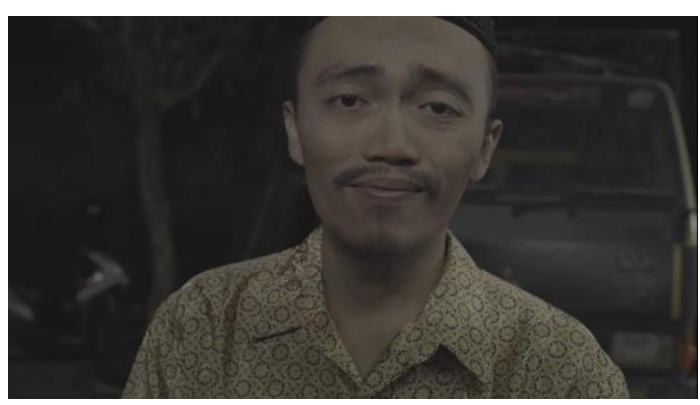

Gambar 8 Screenshot Pak Dukuh berterima kasih

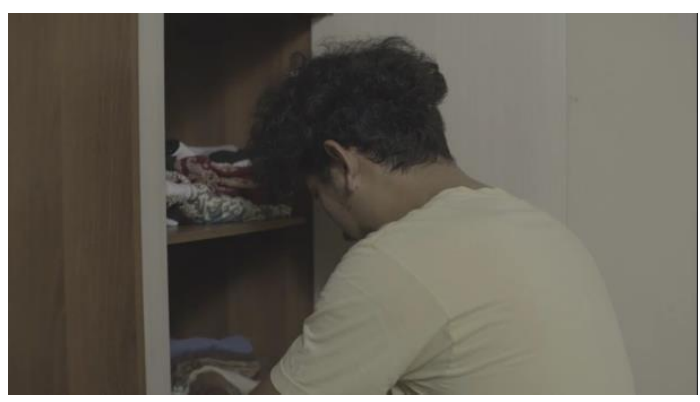

Gambar 9 Screenshot Giman mengambil sepucuk surat 


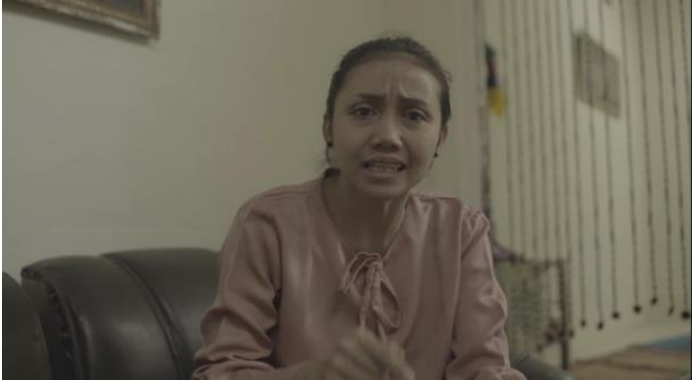

Gambar 10 Screenshot Ririn menasihati Giman dan Ummi

Pada adegan ini mulai ditunjukkan bahwa tanah itu akan diwakafkan sehingga Ririn tidak setuju. Informasi yang muncul sebelumnya juga akan saling terkait. Penonton juga akan mulai mengetahui bahwa selama ini Ummi dan Giman mencoba untuk meyakinkan Ririn tentang wasiat Bapak. Hanya saja belum mendapat waktu yang tepat hingga akhirnya ada momen ketika ada seseorang meninggal dan kehabisan lahan. Semua informasi yang dimunculkan sebelumnya menjadi jelas pada adegan ini. Informasi yang disembunyisembunyikan juga mulai dimunculkan.

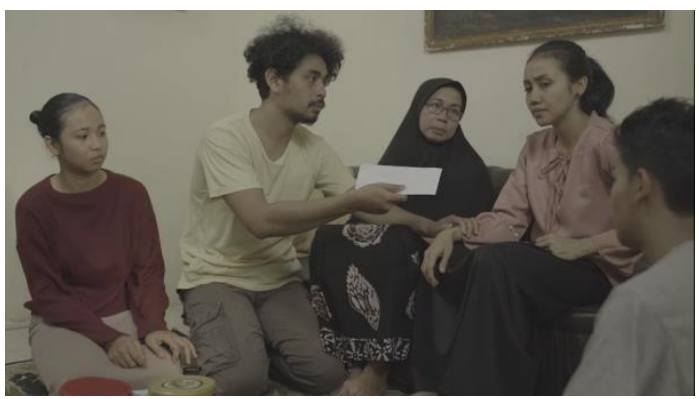

Gambar 11 Screenshot Giman memberikan surat kepada Ririn
Klimaks pada film "Sasanalaya" merupakan titik di mana Ririn mengetahui bahwa tanah yang baru saja dibuatkan sertifikat akan diwakafkan untuk menjadi makam. Ririn yang belum mengetahui tentang wasiat bapak akhirnya mengetahuinya dan menerima apa adanya. Pada adegan ini Penonton juga akan mengetahui bahwa hanya Ririn saja yang belum mengetahui bahwa tanah peninggalan bapak akan diwakafkan. Semua informasi tersembunyi pada film terungkap pada adegan ini. Penonton yang menduga-duga dapat memastikan dugaannya dan segera mengerti sepenuhnya informasi cerita pada film "Sasanalaya".

\section{e. Resolusi}

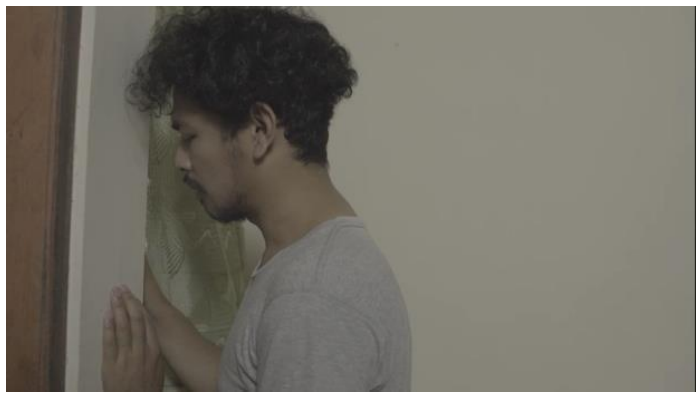

Gambar 12 Screenshot Giman mengintip

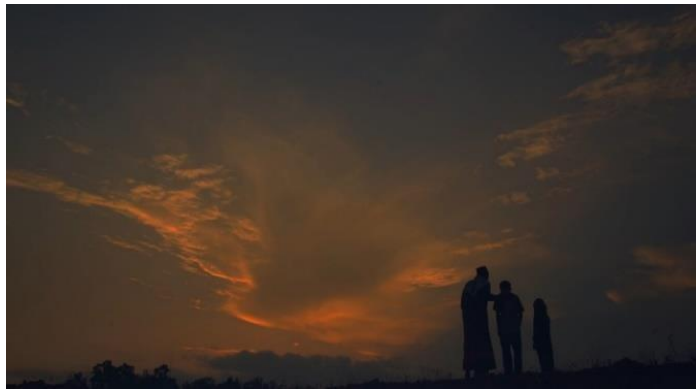

Gambar 13 Screenshot siluet Bapak, Giman kecil, dan Ririn kecil melihat pemandangan 
Ditunjukkan bahwa orang yang mengintip dan mengambil surat di lemari adalah Giman. Sehingga semua menjadi jelas bahwa hanya Ririn yang belum mengetahui soal wasiat itu. Adegan dilanjutkan dengan siluet bapak yang sedang menasihati anaknya, adegan ini digunakan untuk memperkuat keinginan bapaknya mewakafkan tanahnya sekaligus memperkuat agar Ririn mau menerima wasiat Bapak. Informasi sudah sepenuhnya didapatkan oleh penonton kemudian rasa penasaran penonton akan hilang menjadi rasa lega.

\section{Penerapan Penceritaan Terbatas}

Dengan keterkaitan adegan pada tiap scene penerapan penceritaan terbatas pada film "Sasanalaya" dapat diperkuat melalui adegan, blocking, pemilihan shot, dan juga editing. Alur cerita film "Sasanalaya" sudah mendukung teknik penceritaan terbatas. Berikut teknik yang digunakan yang digunakan untuk mendukung penceritaan terbatas pada film "Sasanalaya".

\section{a. Pengadeganan}

Pengadeganan pada film "Sasanalaya" ditekankan untuk memberi efek penasaran kepada penonton. Banyak gelagat dari tokoh yang mencurigakan sehingga dapat membuat penonton mendugaduga maksud dari adegan itu. Selain itu penataan adegan juga diatur agar tokoh Giman terlibat dan tidak hanya menjadi penonton saja, karena tokoh Giman tidak memiliki dialog. Penonton diajak untuk menelaah kejadian demi kejadian pada film kemudian memahami cerita dan informasi yang disampaikan.

Pada adegan di atas Giman memandangi Ummi, setelah ia diminta untuk menelepon Ririn. Adegan itu digunakan untuk menunjukkan kepada penonton bahwa ada informasi yang mereka sembunyikan. Penonton belum mengetahui ada apa di antara mereka berdua atau ada apa dengan telepon Ririn. Informasi tentang maksud dari Ummi menelepon baru akan diperlihatkan pada adegan berikutnya.

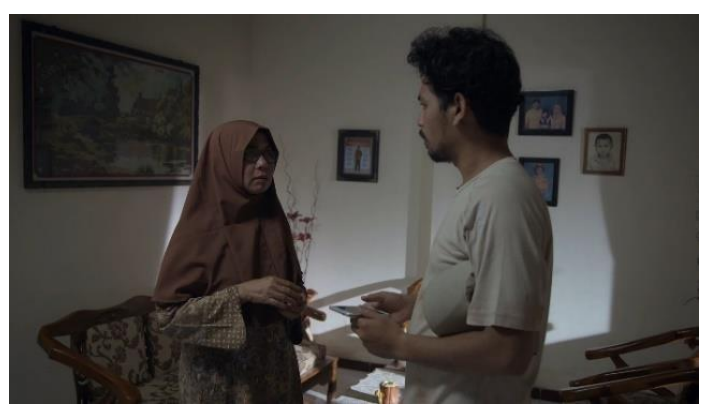

Gambar 14 Adegan Giman memandangi Ummi 


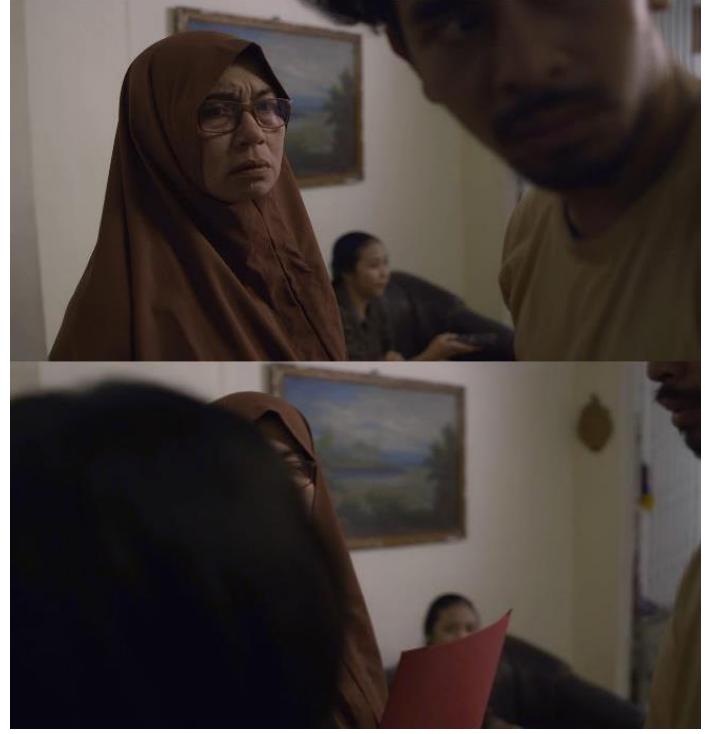

Gambar 15 Screenshot Giman dan Ummi gelisah kemudian Ririn tiba-tiba muncul.

Ketika tiba-tiba Ririn datang penonton sama tidak tahunya dengan Giman. Hal itu akan menimbulkan efek kejutan, karena penonton maupun tokoh sama-sama tidak mengetahui bahwa Ririn tibatiba muncul.

Pengadeganan yang mendukung penceritaan terbatas juga dilakukan dengan pada adegan Giman membaca surat. Kamera yang terus berfokus pada Giman membuat penonton sama-sama tidak mengetahui jika akan ada orang masuk. Sehingga ketika terdengar suara pintu dan Giman terkejut. Penonton juga baru mengetahui informasi bahwa Giman ketahuan setelah Giman terkejut. Hal itu akan memiliki efek berbeda ketika gambar dari orang yang membuka pintu diperlihatkan terlebih dahulu.

\section{b. Penggunaan Sudut Kamera Subyektif}

Derajat paling tinggi dalam penerapan penceritaan terbatas adalah penggunaan sudut kamera subyektif. Dengan menggunakan sudut kamera subyektif, sudut pandang penonton akan sangat terbatas pada sudut pandang salah satu tokoh saja.

Dengan sudut kamera subjektif dianggap berhasil untuk membuat penonton merasa terlibat ke dalam film. Selain itu dapat mendukung pembatasan cerita pada film "Sasanalaya". Pada awal film "Sasanalaya" digunakan sudut kamera subyektif secara penuh. Hal tersebut dapat memberi efek penasaran kepada penonton karena penonton sudut pandang penonton sangat terbatas.

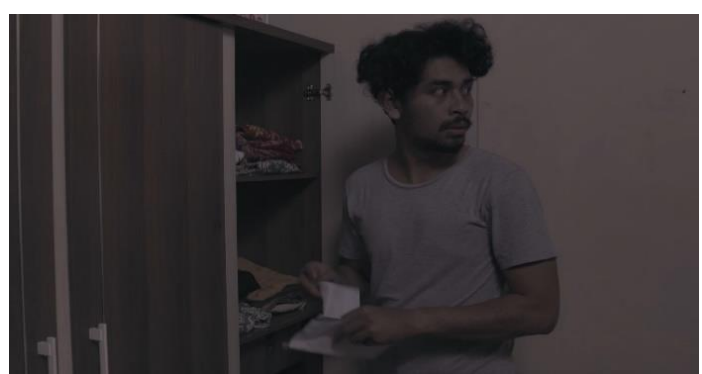

Gambar 16 Screenshot Giman terkejut 


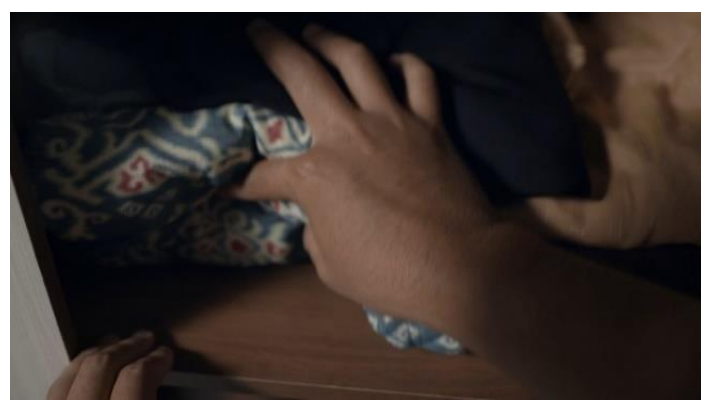

Gambar 17 Screenshot angle subyektif tangan membuka lemari

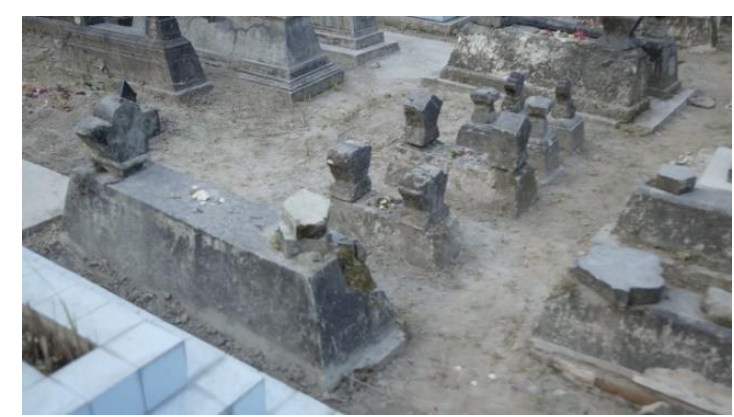

Gambar 18 Screenshot angle subyektif berjalan di antara batu nisan

Pada adegan makam penonton diajak untuk ikut melihat betapa penuhnya makam dan terlihat batu nisan yang kecil. Penonton juga ikut merasakan untuk berjalan di antara batu nisan yang sudah sangat padat. Ketika tokoh Giman inframe hal tersebut akan memberikan efek kejutan karena sebelumnya penonton akan menganggap bahwa itu adalah sudut pandang mata Giman namun tibatiba Giman masuk. Pada adegan ini digunakan untuk menekankan bahwa makam yang dilihat oleh Giman sudah benar-benar penuh. Ketika gambar terlihat seolah mewakili mata Giman penonton diajak untuk ikut serta berjalan di antara batu nisan itu. Kemudian tokoh Giman dimunculkan untuk menyadarkan kepada penonton bahwa mereka sedang mengikuti alur melalui tokoh Giman bukan sebagai Giman. Sekaligus memberi informasi bahwa mereka sedang berjalan seperti yang dilakukan oleh Giman.

Giman terlihat melihat ruang tengah yang berisi Mbak Iyem dan Ridwan. Terdengar suara piring dari arah samping. Kemudian Giman menoleh ke arah pintu. Di balik pintu terdengar suara seseorang sedang mencuci piring. Penonton mengikuti sudut pandang Giman ketika melihat ke arah ruang tengah Giman maupun penonton tidak mengetahui akan ada suara orang mencuci piring. Ketika terdengar suara, Giman menoleh. Penonton akan merasakan pengalaman virtual seperti yang dialami Giman. Ketika Mbak Iyem memandangi kamera dengan penasaran penonton akan merasa dipandangi. Kemudian penonton segera menganggap bahwa ia memandangi Giman yang memiliki gelagat aneh pada adegan sebelumnya. Dari pemaparan di atas dapat disimpulkan bahwa informasi yang diketahui penonton sama atau lebih sedikit dari Giman. 


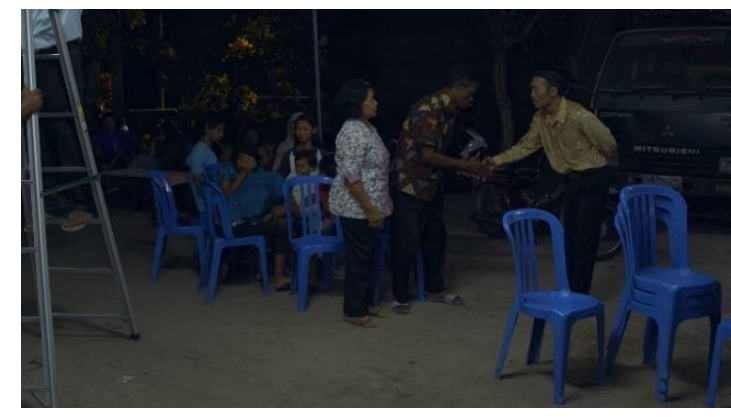

Gambar 20 Screenshot kamera melihat Pak Dukuh dari jauh

Penggunaan sudut kamera subyektif pada scene 15 digunakan secara penuh dengan disertai interaksi dengan tokoh dalam film. Hal ini digunakan untuk membatasi informasi yang didapat oleh penonton agar selalu terkait dengan tokoh utama. Ketika kamera menghampiri Sarno dan Karto, di waktu yang bersamaan kamera melihat ke arah Pak Dukuh sedang berbicara dengan seseorang. Pembicaraan mereka tidak terdengar, penonton sama-sama tidak mengetahui pembicaraan itu seperti tokohnya. Kamera mendekat ke arah Pak Dukuh, baru terdengar bahwa ia sedang mengusahakan lahan untuk pemakaman.

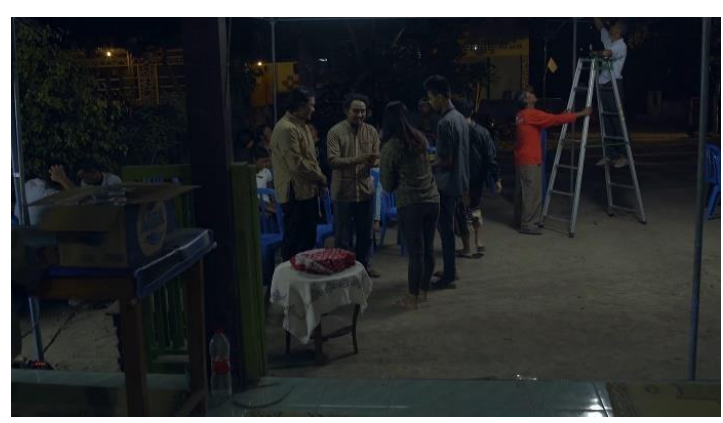

Gambar 21 Screenshot Giman berjalan terdengar warga yang mengobrol
Selain membatasi secara sudut pandang kamera, untuk mendukung penceritaan terbatas, pembatasan melalui suara juga dilakukan dalam film "Sasanalaya". Penggunaan dialog Off-Screen diterapkan dengan cara memunculkan dialog yang dilakukan di luar pandangan tokoh utama atau kamera. Dilakukan untuk memperkuat efek penasaran pada penerapan penceritaan terbatas.

Dialog off-screen diterapkan ketika Giman atau kamera berjalan keluar dari rumah duka. Di belakang Giman terdengar suara warga yang membicarakan tentang penuhnya makam. Penonton mendapatkan informasi terbatas dari sudut pandang kamera. Baru kemudian ketika kamera mengikuti perbincangan tokoh Karto dan Sarno penonton mengetahui lebih lanjut tentang isu penuhnya lahan makam.

Penerapan penceritaan terbatas dapat dilakukan pada berbagai teknik lainnya untuk membatasi informasi. Poin yang paling penting pada pembatasan informasi pada penceritaan terbatas adalah di mana penonton mengetahui informasi yang sama atau lebih sedikit dari tokoh utama. 
Penonton tidak pernah lepas dari tokoh utama, sehingga informasi milik penonton hanya didapat dari alur dan sudut pandang tokoh utama.

\section{Kesimpulan}

Penceritaan terbatas adalah informasi cerita yang dibatasi dan terikat hanya pada satu karakter saja. Penonton hanya mengetahui serta mengalami peristiwa seperti apa yang diketahui dan dialami oleh karakter yang bersangkutan. (Pratista, 2008:39-40) Mata kamera tidak pernah lepas dari tokoh utama.

Pembatasan narasi tersebut memberi efek penasaran karena penonton tidak mengetahui secara pasti apa yang akan terjadi berikutnya. Film "Sasanalaya" merupakan film drama yang dikemas melalui adegan kehidupan sehari-hari. Penceritaan terbatas pada film "Sasanalaya" diterapkan melalui informasi dimunculkan secara tidak langsung dan disembunyi-sembunyikan menggunakan turning point atau peralihan-peralihan.

Efek penasaran yang diberikan kepada penonton didukung dengan permasalahan dalam cerita dan isu yang diangkat pada film. Pemaparan cerita dengan menyembunyikan informasi dan membuat pengalihan perhatian kepada penonton dapat membuat penonton menduga-duga apa yang akan terjadi berikutnya. Informasi yang didapatkan oleh penonton terbatas pada informasi yang juga diketahui oleh tokoh utama bahkan lebih sedikit.

Film "Sasanalaya" menerapkan teknik penceritaan terbatas dengan menyembunyikan informasi bahwa wasiat bapak berupa keinginan untuk mewakafkan tanahnya. Penonton tidak akan mengetahui bahwa tanah tersebut akan diwakafkan sebelum informasi tersebut dimunculkan pada adegan klimaks. Penonton akan menduga-duga informasi tersembunyi itu. Dimunculkannya seluruh informasi di akhir akan ada efek kejutan di mana informasi-informasi yang diperoleh penonton akan saling terhubung dan rasa penasaran penonton akan hilang.

\section{Daftar Pustaka}

Bordwell, David. 2008. Film Art : An Introduction, New York : McGrawHill.

Cassady, Marsh. 1995. Characters in Action: Playwriting the Easy Way. Colorado: Meriwether Publishing Ltd.

Dewojati, Cahyaningrum. 2010. Drama

"Sejarah, Teori dan

Penerapannya”. Yogyakarta :

Gadjah Mada University Press

Effendy, Onong Uchjana . 1896. Televisi Siaran dan Praktek. Bandung : Alumni 
Hariandja, Marihot T.E, 2002.

Manajemen Sumber Daya Manusia

. Jakarta: Grasindo.

Harymawan, RMA. 1993. Dramaturgi.

Bandung: PT Remaja Rosdakarya.

Livingston, Donald L. 1969. Film

and Director, New York : Capricon

Books.

Mascelli, V. Joseph. 1997. The Five

$C$ 's of Cinematography Camera

Angles. California: Cine

Publications Hollywood.

(terjemahan H. Misbach Yusa

Biran).2010. The Five C'S

Cinematography: Motion Picture

Filming Techniques Simplified

(Lima Jurus Sinematografi).

Jakarta: FFTV IKJ

Naratama, 2004. Menjadi Sutradara

Televisi Dengan Single dan Multi

Camera. Jakarta : PT Gramedia

Widiasarana Indonesia.

Pratista, Himawan. 2008. Memahami

film. Yogyakarta; Homerian

Pustaka. Rabiger, Michael, dan

Mick Hurbis-Cherrier . 2013.

Directing Film Techniques and

Aesthetics Fifth Edition. Oxford :

Focal Press

\section{Surat Kabar :}

Kedaulatan Rakyat. 2017, 26 Januari.

Meski Kebutuhan Sudah Mendesak

Lahan Pemakaman Baru Belum

Diprioritaskan. Yogyakarta.

\section{Sumber Online :}

http://www.dorrancepublishing.com/char acter-driven-v-plot-driven-writingwhats-difference/ . Character

Driven v. Plot Driven Writing:

What's the Difference? Diakses

pada 11 Juli 2018

https://dikiumbara.wordpress.com/2012/0

6/27/editing-televisi-linear-dan-

non- linear/ . Editing Televisi:

Linear dan Non Linear. diakses pada 12 Juli 2018

http://www.definisimenurutparaahli.com/ pengertian-artistik/Pengertian

Artistik. diakses pada 12 Juli 2018 